\title{
Przysięga dowodowa w polskim prawie miejskim i ziemskim w XVII-XVIII wieku. Model normatywny oraz praktyka sądowa na przykładzie wybranych mniejszych miast województwa pomorskiego i malborskiego, a także sądu grodzkiego w Kiszporku
}

Drzysięga należała do najczęściej stosowanych i najprostszych

$1 \mathrm{w}$ przeprowadzeniu środków dowodowych. Decydował o tym fakt, że teoretycznie możliwa była do użycia w każdej niemal sprawie oraz na każdym etapie postępowania czy to jako dowód bezpośredni, czy też akcesoryjny (pomocniczy). Wystarczało jedynie oświadczenie danej osoby potwierdzające lub zaprzeczające określnym faktom (faktowi), złożone $\mathrm{w}$ odpowiedniej formie, przed właściwym organem bądź jego przedstawicielami. Podparta powołaniem na Boga i krucyfiks, mogła okazać się decydująca, stając się tym samym podstawą wyroku. Warto więc bliżej przyjrzeć się kilku aspektom tego dowodu, którego znaczenie - jak słusznie zauważył Marian Mikołajczyk - bywa niekiedy negowane, pomimo że jak pokazuje praktyka sądowa znajdował zastosowanie jeszcze w końcu XVIII w. ${ }^{1}$

Przedmiotem niniejszego artykułu jest przysięga jako środek dowodowy zbadany na podstawie zapisów wczesnonowożytnych akt miejskich wybranych ośrodków Prus Królewskich oraz jednego z tamtejszych sądów grodzkich. Skupiono się na kilku mniejszych miastach dawnego województwa pomorskiego i graniczącego z nim województwa malborskiego. Podstawę stanowi materiał pochodzący z Nowego nad Wisłą (Neuenburg), Kościerzyny (Berent), Chojnic (Konitz), Sztumu (Stuhm) i Skarszew (Schoeneck). Bogate i w większości dobrze zachowane archiwa pozwalają na szczegółową analizę tematu, w szerszej perspektywie terytorialnej oraz czasowej, a dzięki badaniom porównawczym jej wyniki można odnieść do innych, podobnych ośrodków Korony oraz modelu

${ }^{1}$ M. Mikołajczyk, Proces kryminalny w miastach Małopolski XVI-XVIII wieku, Katowice 2013, s. 372; por. S. Borowski, Przysięga dowodowa w procesie polskim późnego średniowiecza, Warszawa 1926, s. 12-13. 
tam wykształconego. W sumie dla rozpatrywanego okresu dysponujemy ponad 150 księgami miejscowych sądów ławniczych oraz rad miejskich, zlokalizowanymi w trzech zasobach: Archiwów Państwowych w Bydgoszczy i Gdańsku oraz Biblioteki Zakładu Narodowego im. Ossolińskich we Wrocławiu. Obok nich sięgnięto do zespołu leżącego w województwie malborskim sądu grodzkiego w Kiszporku (Dzierzgoniu). Jest on mniej zasobny (55 ksiąg), ale zawiera sporo interesujących nas materiałów, które dodatkowo uzupełniają zespoły miast, gdyż szlachta Prus Królewskich dość często korzystała $\mathrm{z}$ archiwów miejskich, wpisując $\mathrm{w}$ nie szereg różnego rodzaju dokumentów prywatnych i publicznych. $Z$ racji utraty znacznej części archiwaliów szlacheckich stanowią one pierwszorzędne źródło w rozważaniach dotyczących pruskich posesjonatów. Dodatkowo powyższy materiał praktyki sądowej skonfrontowano ze źródłami normatywnymi. W ten sposób ukazano nie tylko prawne tło przysięgi, ale również jej praktyczny wymiar w codziennym życiu mieszczan oraz szlachty Prus Królewskich w XVII-XVIII w.

Podstawą orzeczniczą dla wskazanych miast, jak i większości pruskich gmin była lokalna odmiana prawa magdeburskiego - prawo chełmińskie (ius culmense). W toku swojego rozwoju nie wykształciło ono jednej, powszechnie obowiązującej kodyfikacji, choć próby jej stworzenia w II połowie XVI w. zaowocowały trzema poważnymi projektami. Były to: Rewizja Lidzbarska z 1566 r. ${ }^{2}$, Nowomiejska z roku $1580^{3}$ i Toruńska opracowana w $1594 \mathrm{r}^{4}$ Mimo że uznaje się je za kompilacje dość udane, nie otrzymały one akceptacji stanów, zorientowanych w tym czasie na realizacje interesów partykularnych, ani też króla, który wykazując zainteresowanie spisaniem prawa, jednocześnie nie usankcjonował żadnej z nich. Niemniej jednak używane były w codziennym obrocie prawnym, skutecznie wypierając kodyfikacje wcześniejsze, przede wszystkim XIV-wieczne Prawo Starochetmińskie (Der alte Kulm) ${ }^{5}$. To ostatnie, mocno jeszcze oparte na rozwiązaniach magdeburskich, stanowiło wzór dla opracowania pierwszej rewizji (Lidzbarska), z której korzystano w dalszych próbach kodyfikacyjnych (Nowomiejska, Toruńska). Wskutek tego duża

${ }^{2}$ Rewizja lidzbarska prawa chetmińskiego 1566 [1711], przekł. A. Groth, Koszalin 1997 [dalej: RL].

${ }^{3}$ Rewizja nowomiejska prawa chetmińskiego 1580 (1814) zwana także ius culmense emendatum lub ius culmense polonicum, red. Z. Zdrójkowski, przekł. I. Malinowska-Kwiatkowska, J. Sondel, Torun 1993 [dalej: RN].

${ }^{4}$ Ius Culmense ex ultima revisione oder das vollständige Kulmische Recht, wyd. M. C. Hanow, Danzig 1745; wyd. 2, Danzig 1767.

${ }^{5}$ Prawo starochetmińskie 1584 (1394), red. W. Maisel, Z. Zdrójkowski, przekład A. Bzdęga, A. Gaca, Toruń 1985 [dalej: PS]. 
część materii znanej z Der alte Kulm, w tym regulacja przysięgi', znalazła się później w kodyfikacjach XVI-wiecznych. Z kolei dla posesjonatów od 1598 r. głównym źródłem prawa stała się Korektura Pruska ${ }^{7}$. Powstała ona w efekcie konfliktu z mieszczanami oraz niemożności pogodzenia interesów obu stanów, uwzględniając wszystkie ważniejsze postulaty szlachty, m.in. kontrowersyjny ustrój rozdzielności dóbr małżonków, którego nie akceptowały miasta uznając za niezgodny z podstawową dla prawa chełmińskiego wspólnotą majątkową (tzw. połową chełmińską communio bonorum). Zbiór ten nie był natomiast kodyfikacją pełną. Poza materią normatywną pozostało szereg - niekiedy ważnych - instytucji, co powodowało konieczność sięgania do bardziej rozbudowanych kompilacji mieszczańskich (np. Rewizji Toruńskiej) bądź do rozwiązań stosowanych $\mathrm{w}$ tym czasie $\mathrm{w}$ prawie koronnym.

O formie złożenia przysięgi krótko pouczał już art. 62 ks. II Prawa Starochetmińskiego. W tytule Jak się przysięga nakazano, aby położyć palce na relikwiarzu i nie zdejmować ich, aż do wyraźnego zezwolenia sędziego pod groźbą przegrania sprawy oraz zapłaty mulkty ${ }^{8}$. Jeszcze mniej na ten temat mówiły rewizje i Korektura Pruska, przy czym do przysięgi jako środka dowodowego odnosiły się w co najmniej kilkunastu miejscach. Bardziej szczegółowo proces przysięgania omówił XVI-wieczny komentator prawa magdeburskiego, krakowianin Bartłomiej Groicki. W Porzadku sąów zawarł on wzorcowy model przysięgi wraz z odpowiednimi formułami, jakich miała trzymać się osoba zobligowana do jej odłożenia ${ }^{9}$. W skrócie wyglądał on następująco. W oznaczonym dniu i miejscu zjawiali się powód, pozwany oraz ich rzecznicy. Rzecznik składającego przyrzeczenie potwierdzał gotowość do przysięgania, po czym pisarz odczytywał wcześniej ustaloną rotę (forma/rota iuramenti, iuramentum), przestrzegając jednocześnie przed ewentualnymi pomyłkami. Dalej procurator pytał sędziego „[...] jako do znaku Męki Pańskiej pryncypał jego ku oddaniu przysięgi przystąpić ma?", sędzia zaś nakazywał przysięgającemu uklęknięcie. Następnie podawano mu krucyfiks lub relikwiarz, na

${ }^{6}$ Np. RL, s. 71 (art. 1); 72 (art. 2); 76-78 (art. 13-14); 79 (art. 18); 93 (art. 29); 122 (art. 22); 124 (art. 27); 125-126 (art. 28, 30), 134 (art. 47), 136 (art. 52); 163 (art. 110).

${ }^{7}$ VL, t. VI; D. Patterson, Ius terrestre nobilitatis prussiae correctum Anno Domini M. D. XCVIII, Gedani 1627.

${ }^{8}$ PS, s. 53. Późnośredniowieczny rytuał składania przysiąg w Prusach omówili ostatnio M. Duda, S. Jóźwiak, Sposoby składania przysięgi w Państwie Zakonu Krzyżackiego w Prusach w późnym średniowieczu. Zarys problematyki, „Zapiski Historyczne” 2014, t. LXXIX, z. 1, s. 5-34; zob. też tenże, Ze świata średniowiecznej symboliki. Gest i forma przysięgi w chrześcijańskiej Europie (X-XV w.), Kraków 2014.

${ }^{9}$ B. Groicki, Porzadek sądów i spraw miejskich prawa majdeburskiego w Koronie, wyd. K. Koranyi, Warszawa 1953, s. 145-148. 
który ten kładł dwa palce wypowiadając treść przyrzeczenia. Na końcu rzecznik potwierdzał fakt ukończenia dowodu oraz kierował zapytanie o zezwolenie na zdjęcie palców z krzyża, a sędzia wyrażając je finalizował czynność końcowymi formułami.

Czy jeszcze w XVII- i XVIII-wiecznych Prusach trzymano się tak podniosłego i formalnego rytuału, skoro już w XVI w. Groicki w swoich Tytułach prawa magdeburskiego zauważył liczne od tego odstępstwa? ${ }^{10}$ Możemy stwierdzić, że z pewnością nie zważano w szczególny sposób na miejsce przysięgania. Składano przysięgę zwykle tam, gdzie dokonywano danej czynności prawnej czy procesowej (np. przy sesjach wyjazdowych sądu) bądź po prostu tam, gdzie aktualnie odbywały się rozprawy sądowe (np. ratusz, dom sędziego, burmistrza). Wydaje się, że liczyło się przede wszystkim to, kto przyjmował oświadczenie oraz jak przysięgano. Liczne zapisy informują o przysiędze uczynionej na krucyfiks, w pozycji klęczącej i z palcami uniesionymi ku górze. Co prawda brak jakichkolwiek zapisów, żeby stosowano, krok po kroku, każdą podaną przez Groickiego sentencję, ale jak wynika z akt sądowych zachowane były podstawowe wymogi zawarte w jego komentarzach: uklęknięcie, użycie krucyfiksu i - co można dodać, a nie za często podkreśla się to w materiale źródłowym, bo była to dla współczesnych sprawa nader oczywista, przysięgający składał przyrzeczenie bez nakrycia głowy. Przykładowo, zapis z ksiąg Nowego nad Wisłą z kwietnia 1669 r. informuje, że w sprawie dotyczącej niewyjaśnionej śmierci owczarza z Komorska, Krystiana Kryziona, świadek Michał Forman (22-letni owczarczyk z Nowej Wsi) oraz inne, zeznające $w$ niej osoby ,"...] przysięgę swoją przed sądem naszym potwierdził [...] klęknąwszy i dwa palca przed krucyfiksem każdy z nich podniowszy in hanc iuramenti Rotam przysięgli"11. W taki sam sposób przyrzekali kilka dni później dalsi świadkowie. 84-letni Michał Zemrow i 50-letni Mathias Eggert, poświadczający przed delegatami rady miejskiej Chojnic (1694 r.) „dobre urodzenie" mieszkańca Polnic - jak zanotowano - „oboje ludzie wiary godni stanęli oblicznie przed sądem i aktami miejskimi naszymi chojnickimi, którzy po napomnieniu strony fałszywego oddania świadectwa pod sumieniem swym zeznali i poprzysięgli z odkrytymi głowami, wyciągnąwszy prawych rąk i podniąwszy dwa palce"12. W 1609 r. dwaj posesjonaci Walenty i Andrzej Żeromscy skarżyli się przeciwko sędziemu powiatu mirachowskiemu, Wojciechowi Kierzyńskiemu i jego małżonce

${ }^{10}$ Tenże, Tytuly prawa maydeburskiego do porzadku i do artykułów, pierwey po polsku wydanych. W sprawach tego czasu naywięcey kłopotnych z tegoż prawa maydeburskiego przydatne, Kraków 1760, s. 148-158.

${ }^{11}$ APB, 196/75a, s. 79-81.

${ }^{12}$ APB, 1675/39, s. 304-305. 
Elżbiecie. Przedmiotem sprawy był konflikt dotyczący Jeziora Raduńskiego. Obaj „,klęknowszy na kolana swe i ku górze podniowszy dwa palce przysięgali, że" sprowadzonych ze sobą świadków, którzy mieli potwierdzić ich zeznania, nie podkupili13. ${ }^{13}$ Rok później, w postępowaniu spadkowym, na kolanach i z podniesionymi palcami swoją przysięgę składał szlachcic Bartosz Piersczewski ${ }^{14}$. Podobne przykłady można mnożyć ${ }^{15}$.

Krucyfiks nie zawsze był jednak konieczny. W zależności od sprawy, potrzeb czy okoliczności można było go zastąpić innym przedmiotem - świętym obrazem czy katowskim mieczem. I tak np. w 1721 r. bracia Jakub i Krzysztof Wróblowie z Brus przysięgali klęcząc przed obrazem przedstawiającym wizerunek Jezusa Chrystusa ${ }^{16}$. Wcześniej, w Chojnicach, rodzeństwo składało przysięgę kładąc palce na miecz tamtejszego kata, po czym zostali wyświęceni z miasta ${ }^{17}$.

${ }^{13}$ APGd, 506/2, s. 131-132.

${ }^{14}$ Tamże, s. 220.

${ }^{15}$ Zarówno dla XVII-XVIII w., jak i okresu wcześniejszego, przede wszystkim wieku XVI. W 1563 r. mieszczanin kościerski, niejaki Marek przysięgał „,[z - P.K.] odkryta głowă wyciągnioną ręka, podniesionymi ku górze palcami ku Bogu i jego świętemu słowu" (APGd, 506/1, s. 170). W 1599 r. przed sądem Kościerzyny przysięgę składał sławetny Piotr Gliszczyński. 80-letni starzec czynił to „,[...] będąc [...] do prawa przywołany [...] palce swe ku górze [...] szczerze podniowszy". Tak samo przyrzeczenie składali inni wezwani, BZNiO, 4411/II, k. 71 i n., por. BZNiO, 4410/II, k. 49v-50 (Sobański, 1584, Kościerzyna); BZNiO, 4411/II, k. 95 (Łukasz Klinkosz, Michał Chwaryk, 1601, Kościerzyna); tamże, k. 96-97 (Wojciech Gostomski, Wojciech Żukowski, Paweł Żukowski, 1601, Kościerzyna); tamże, k. 105v-106 (Bartosz Kubisz, Tomasz Petc, Jan Sobysz, 1603, Kościerzyna); tamże, k. 122-123 (Michał Płachecki „przysięga [...] klęknąwszy na kolana swoje y 2 palca podniowszy ku górze", 1605, Kościerzyna); tamże, k. 127v-128 (Filip Niepoczotowski, Jan Lewiński, Piotr Niepoczotowski, Janusz Osiecki, Janusz Niepoczotowski „,[..] klęknąwszy na kolana y 2 palca podniowszy ku górze przysiąg”", 1605, Kościerzyna); tamże, k. 131 (Hans Kragansky, 1606, Kościerzyna); tamże, k. 129 (Piotr Mściszewski, 1607, Kościerzyna); APGd, 506/4, k. 130 (Mośińscy, 1749, Kościerzyna); APGd, 3/4, s. 104-106 (1750, Sztum); APGd, 520/25, k. 22 (Otto Wilhelm Wedzek, Anna Maria Relowa, 1754, Skarszewy); A. Pryłowski, Czy istniał patrycjat w małych miastach? (Na przykładzie Nowego n. Wista I połowy XVIII w.), "Gdańskie Studia Humanistyczne” 1970, R. XIII, nr 7, s. 78; APB, 1675/147, s. 328-329 (Piechowski, 1763, Chojnice); APGd, 524/13, s. 388 (David Eggiert, Jan Szulc, 1770, Sztum). O krucyfiksie w przysiędze składanej przed sądem ziemskim m.in.: APGd, 2/7, s. 213 (1670, sprawa o granicę dóbr), 580 (1672, sprawa między Samuelem Czarlińskim a Janem Olszowskim o wydanie poddanego). W 1770 r. toczyło się postępowanie przeciw sztumskiemu rajcy i sędziemu Gottliebowi Szumanowi. Pośród kilku zarzutów pojawił się też dotyczący rzekomego znieważenia krzyża, gdy podczas jednej z sesji sędzia miał poprawiać stojący na stole krucyfiks i powiedzieć ",[...] ja w to nie wierzę [w krucyfiks - P.K.], to tylko jest cyna jak mówią Lutrzy, że my w to wierzymy [?] [...]", APGd, 524/13, s. 433-434.

${ }^{16} \mathrm{BZNiO}, 3181 / \mathrm{II}, \mathrm{k} .50-50 \mathrm{v}$

${ }^{17} 31$ I 1721 r. stanęli oni przed magistratem Kościerzyny, by złożyć skargę przeciw radzie i miastu Chojnice, przez które zostali posądzeni o rozliczne przestępstwa (m.in. kra- 
Pomyłki czy mniejsze lub większe przeinaczenia, jakie z pewnością zdarzały się w trakcie aktu przysięgania, najprawdopodobniej w XVII w. nie miały już większego wpływu na ważność przysięgi. Brak jest w materiale źródłowym jakichkolwiek zapisów sugerujących upadek w sprawie z ich powodu bądź powstanie innych, negatywnych konsekwencji, może poza koniecznością powtórzenia przez stronę swoich słów. Faktem jest natomiast, że księgi miejskie i ziemskie tylko z rzadka rejestrowały procedurę przeprowadzania dowodu z przysięgi, skupiając się przede wszystkim na odnotowaniu finalnego efektu - odłożenia przyrzeczenia oraz treści jego roty.

Ta z kolei była przedstawiana przez organ, przed którym toczyło się postępowanie. Z reguły to spisujący protokół pisarz sądowy podawał ją do wiadomości, a po wypowiedzeniu przez zobowiązanego, wpisywał następnie do czystopisu. Treść zależała od meritum sprawy, określonych żądań stron czy inwencji samych urzędników. Można przy tym wskazać na podstawowe elementy roty. Zawierała ona mniej lub bardziej dokładne określenie osoby, która ją odkładała (intytulacja), stwierdzenie charakteru

dzież), zatrzymani na wolnej drodze, związani i przewiezieni do miasta, gdzie poddano ich torturom. Przez 18 kolejnych tygodni byli głodzeni i regularnie badani przez kata, który jednak nie uzyskał od nich przyznania się do winy. W obliczu zwolnienia zmuszono ich do złożenia przysięgi, że nie będą się mścić oraz toczyć sporów prawnych z Chojnicami czy z tamtejszym wójtem. Przed sądem kościerskim przysięgli: „Przysięgam Panu Bogu Wszechmogącemu w Trójcy Świętej Jedynemu, iż ja nic złego nikomu nie uczyniwszy, ani nic nieukradłwszy, od urzędu, sądu i całego miasta Chojnic, będąc złapany, wiązany na dobrowolnej drodze, po tym [...] więzienie cierpiąc przez niedziel osiemnaście, na tortury co raz brany i dręczony, głodem morzony, na ostatek za niewinność moją abym się nie mścił, na drogach nie zastępował i z miastem nie prawował, przez Pana Wójta do przysięgi przymuszony, którą przysięgę położywszy na miecz odłożyć musiałem i przez kata ze miasta wyprowadzony byłem. Tak mi Panie Boże dopomoż i niewinna Męka Syna Jego" (BZNiO, 3181/II, k. 50-50v). Było to o tyle kontrowersyjne, że już Szczerbic pouczał, że ,[...] kto tak drugiego do przysięgi przymusza/gorszy jest niż mężobójca/albowiem mężobójca ciało/a ten dusze zabija" (P. Szczerbic, Speculum Saxonum..., Lwów 1581, s. 192). Mieszczanin skarszewski Jan Dusza, podejrzany o zaprószenie w 1738 r. ognia w mieście, był poddany torturom trzykrotnie. Wzięty po raz pierwszy na inkwizycje przyznał się jak sam zaznaczył - „ze strachu” do podpalenia, aczkolwiek niedługo po tym zeznania odwołał. Po trzecim cyklu tortur został zobowiązany do złożenia przed radą przysięgi, w której - po pierwsze - kolejny raz zaświadczył o swojej niewinności; po drugie - zrezygnował z roszczeń wobec miasta i jakiejkolwiek formy zemsty: „póki będę żył [...], ani uczciwej całej radzie, ani całemu miastu, w najmniejszych rzeczach mścić się nie chce, ni krewnych moich, ani cudzego do tego namawiać nie będę, a gdybym podejrzał, że kto inny, pod moim imieniem co z tego aby się pomścił uczynić chciał, ile możności mojej bronić tego i mojej [Z]wierzchności jak najprędzej opowiedzieć [...]. Tak mi Panie Boże Dopomóż" (APGd, 520/23, f. 131). Nadto przyrzekł, że od tej pory będzie obchodził się ostrożniej z ogniem. Należy uznać, że przynajmniej w tym ostatnim punkcie przysięgi dotrzymał. 
dowodowego, przedmiot przyrzeczenia (fakt zaprzysięgany ${ }^{18}$ ) oraz zwyczajowe odwołanie religijne (inwokacja) ${ }^{19}$. Dość dobrze obrazuje to przysięga złożona w 1750 r. przez syna Marianny Rzeszewicz z Kościerzyny. Przedmiotem postępowania był spadek, którego kompletność podana została w wątpliwość, więc dokonująca podziału komisja postanowiła, że jego inwentarz zostanie poprzysiężony. Spadkobierca oświadczył: „Ja Jakub Rzeszewicz przysięgam Panu Bogu Wszechmogącemu w Trójcy Świętej Jedynemu, iż ja nic więcej z fortuny macierzystej, tak za życia matki mojej jako też i po śmierci jej tak pieniędzmi jako też i ruchomościami lub sprzętami domowymi i inwentarzem, tudzież i sukcesji po bracie moim Marcinie Rzeszewiczu mnie przypadającej oprócz złotych 30 in vim sukcesji i oprócz ojczystej fortuny mnie samemu należącej, którą realnie odebrałem stante vita matki mojej nie odebrałem, a i też żadnemu człowiekowi, tak z pieniędzy, z[e] sprzętów domowych i gospodarskich, z bielizny, szat, z pościeli matki mojej, z inwentarzów i z innych ruchomości, bynajmniej nie wydałem, ani podać na teraźniejszy inwentarz zataiłem i z tego wszystkiego wyżej opisanego na swój własny lub kogokolwiek, tak krewnego jako i cudzego umyślnie z krzywdą ojczyma mego pożytek nie obróciłem. Tak mi Panie Boże dopomóż i niewinna Syna Jego Męko"20. Blisko 40 lat wcześniej, w podobnym postępowaniu swoje przyrzeczenie składały siostry Marianna i Dorota Gras (Nowe) „Ja Marianna, Ja Dorota, przy P[anu] B[ogu] w [Trójcy] Ś[więtej] J[edynemu] jakośmy brata naszego Macieja Grasa w rozdziale uczynionym po św. pamięci nieboszczyka Jana Grasa sądowego tutejszego w niczym, tak w ruchomych, pieniężnych, w złocie, w srebrze, w cynie, w koprowinie, w bieliźnie nie ukrzywdzili, tak nam Panie [Boże] dopomóż i Męka Chr[ystusa]"21.

Nieraz intytulacje pomijano, gdyż personalia osoby przysięgającej wynikały wprost z treści czynności. Wtedy to przysięga zaczynała się od zwyczajowego ,ja"22, słowa „przysięgam"23 czy wskazania na stan cywilny (małżonek, żona, wdowa, wdowiec), pełnioną funkcję bądź wykonywany zawód (cieśla, karczmarz, ławnik, rajca, burmistrz etc.), pozwalające na bezpośrednią identyfikacje wypowiadającego przysięgę.

W każdym natomiast przypadku znajdujemy elementy religijne. Najczęściej składało się na nie jedno, krótkie zdanie kończące. Tak jak w śre-

${ }^{18}$ S. Borowski, Przysięga dowodowa..., s. 37.

${ }^{19}$ B. Groicki, Porzadek sadów..., s. 143-144.

${ }^{20}$ APGd, 506/4, k. 147v-148.

${ }^{21}$ APB, 196/90, s. 14.

${ }^{22}$ Lub z podaniem dodatkowo imienia, np. „Ja Regina przysięgam P[anu] Bogu Wszechmogącemu [...]", BZNiO, 3182/II, k. 132.

${ }^{23} \mathrm{~Np}$. BZNiO, 3180/II. K. 7v (1680), 8v-9 (1680). 
dniowieczu miało ono unaocznić sakralny wymiar przyrzeczenia (w wymiarze błogosławieństwa, a jednocześnie przekleństwa) ${ }^{24}$, z konsekwencjami dla krzywoprzysiężcy wykraczającymi poza świat doczesny, gdyż powoływano się na Boga ${ }^{25}$, mękę Jezusa Chrystusa ${ }^{26}$ czy „Świętą Ewangelię" ${ }^{27}$. Jak podkreślał Groicki „,...] kto bierze na daremno imię boże, a swego fałszu w nim potwierdza, pewna a nieomylna rzecz jest, iż pomsty od Boga nie ujdzie" 28 . Dlatego radził, aby do przysięgi podchodzić z „dobrą bacznością i sprawiedliwie", tak by poprzez obrazę Boga nie skazać się na wieczne potępienie. Niemniej jednak zdarzają się dłuższe wpisy dewocyjne, pokazujące wycinek ówczesnej mentalności oraz duchowość mieszczan Prus Królewskich. Interesująca w tym względzie jest np. przysięga dotycząca pożyczki niejakiego Grzegorza Kowkowskiego, złożona przed ławą Nowego w 1718 r.: ,[...] Ja Grzegorz Kowkowski, przysięgam P[anu] B[ogu] Wsz[echmogącemu] w Trójcy Świętej Jedynemu, iż żona moja pożyczyła [...] Fryderykowi gburowi talarów 40, na które nic więcej nie odebrała jak t[alarów] 30. Na co jeżeli niesprawiedliwie przysięgam, żeby P[an] Bóg tu obecnym na mię pokazał, [...] żeby piorun mnie trzasnął i jeżeli niesprawiedliwie przysięgano, żeby mię ciężka choroba ogarnęła, żebym ja członkiem jednym władnąć nie mógł i jeżeli niesprawiedliwie przysięgano, żebym się tu zaraz w oczach was obecnych zapadł, [...] żeby P[an] B[óg] czartów z piekła zesłał, żeby zaraz duszę i ciało moje do piekła wzięli na wieczne potępienie, tak mi P[anie] B[oże] dopomóż i Męka Chrystusowa"29.

Spektrum podmiotów zobowiązanych bądź uprawnionych do złożenia przyrzeczenia było stosunkowo szerokie. Przysięgi składać nie mogli tylko orzeczeni krzywoprzysiężcy, cieszący się złą sprawą banici, infamiści, heretycy, niepełnoletni oraz inne osoby nie posiadające pełnej zdolności procesowej ${ }^{30}$. Kilka wzmianek z mniejszych miast informuje także, że

${ }^{24}$ S. Borowski, Przysięga dowodowa..., s. 11.

${ }^{25}$ Np. APGd, 524/10, s. 6 (1759, Sztum); APB, 196/12, s. 303 (1666, Nowe).

${ }^{26}$ APGd, 520/14, k. 57 (Michał Ruchniewicz, Stanisław Przytarski, Jan Czuryłowski, 1755, Skarszewy).

27 „Ja Anna Maria Relowa Panu Bogu Wszechmogącemu przysięgam, iż te zelżywe słowa, które uczciwa Barthelsowa przeciwko sławetnej radzie wyrzekła, które ja osobiście słyszałam y przed urzędem zeznałam od uczciwej Barthelsowej były mówione y z jej ust wyrzeczone, tak mi Panie Boże dopomóż y Święta Ewangelia". APGd, 520/25, k. 22 (1754, Skarszewy).

${ }^{28}$ B. Groicki, Porządek sąów..., s. 143; J. W. Sedlar, East Central Europe in Middle Ages, 1000-1500, Seattle 1994, s. 322-323.

${ }^{29}$ APB, 196/92, s. 81.

${ }^{30}$ P. Dąbkowski, Prawo prywatne polskie, t. I, Lwów 1910, s. 195-197; S. Borowski, Przysięga dowodowa..., s. 21-31; P. Kitowski, N. Radecka, Normatywny model opieki nad sierotami 
nie powinno się jej przyjmować od człowieka, który ukończył 70. rok życia. I tak, pod koniec sierpnia 1719 r. przed radą Nowego stanął ",dziadek” ze szpitala przy kościele pw. św. Jerzego, Jan Skrobiniorek. Opowiedział on dość nieprawdopodobną historię ${ }^{31}$. Wypiwszy sporą ilość alkoholu, nocował na przedmiejskim cmentarzu. Wczesnym rankiem zobaczył ducha posądzonej o czary i zmarłej niedawno na torturach Anny Szpornawskiej, która kazała mu pójść do męża nie realizującego jej próśb o modlitwy za duszę ${ }^{32}$. Zlękniony, szybko wrócił do szpitala, a stamtąd trafił do magistratu. Napomniany o konsekwencjach prawnych opowieść tę chciał poprzysiąc. Zreflektowano się natomiast, że „,...] prawo zakazuje, aby przez siedemdziesiąt lat mającym, nie pozwalać przysięgi, więc i pomienionemu Skrobiniorkowi, który ma przez osiemdziesiąt lat nie pozwala

w XVI-wiecznych rewizjach prawa chetmińskiego. Zarys instytucji, CPH, 2012, t. LXIV, z. 1, s. $121-125$.

${ }^{31}$ APB, 196/93, s. 101-102.

32 Zob. J. Wijaczka, Polowanie na czarownice i czarowników w Nowem nad Wisła i najbliższej okolicy miasta w XVII i w pierwszej połowie XVIII wieku, "Czasy Nowożytne" 2009, t. XXII, s. 119-144; zob. też tenże, Procesy o czary przed sądami miejskimi $i$ wojewodzińskimi w Skarszewach w końcu XVII i w pierwszej połowie XVIII wieku, [w:] Prusy i Inflanty między średniowieczem a nowożytnością. Państwo - społeczeństwo - kultura, red. B. Dybaś, D. Makiłła, Torun 2003, s. 81-96. W 1655 r. o uprawianie czarów posądzona została niejaka Gertruda Czarowa. Kobietę pomówiła inna pozwana, mianowicie Elżbieta Jakuba, której niedługo po tym udało się zbiec z więzienia. Czarowa nie potwierdziła oskarżeń, zobowiązano ją więc do przysięgi następującej treści: „Ja Gertruda Czarowa, przysięgam P[anu] Bogu wszechmogącemu, w św[iętej] Trójcy jedynemu i wszystkim świętym, że na to com była pomówiona od Elżbiety Jakubkej strony czarów, która po tym Elżbieta po pomówieniu mię z więzienia uciekła, na które ja pomówienie nie mając inszej próby siebie uwolnić, tą tedy przysięgą moją teraz sobie [o]bierając $\mathrm{P}$ [ana] Boga na świadectwo potwierdzam, żem jako żywo nikomu nic złego czarami nie uczyniła, anim tego w pomyśleniu miała, i od tego czasu nikomu do śmierci uczynić nie myślę. I to też przysięgam, że tak na dobrach jankowych, jako i na osobie Jmsc Pana Podstarościego i wszystkich zamkowych, jako i poddanych i dobytkach ich, także też na urzędzie miejskim tutejszym, jako i wszystkich obywatelach miejskich i dobytkach ich, ani przez się, ani przez żadne sporządzone osoby, nigdy się mścić nie będę, ani chce i owszem, co się kolwiek działo, w zapamiętanie obracam. Tak mi P[anie] Boże pomóż i męka P[ana] Jezusa Chrystusa" (APB, 196/70, s. 95-96). Po niej przysięgę, w której potwierdzano niewinność oraz rezygnowano z zemsty złożyli mąż podejrzanej (Walenty Czara) oraz brat (Marcin Czara) (APB, 196/70, s. 96-97). W 1689 r. jako czarownica została wywołana mieszkanka jednego z nowskich szpitali. Pomimo trzech cykli tortur, nie przyznała się do „czarostwa”, postanowiono więc wygnać ją z miasta (na 10 mil), przed tym jednak miała złożyć uroczystą przysięgę: „Ja Regina (Reina?), przysięgam P[anu] Bogu wszechmogącemu, w Trójcy Ś[więtej] Jedynemu, iż ja miastu temu i każdemu z osobna [jego mieszkańcowi - P.K.], w niczym sprawą diabelską nie chce szkodzić, ani też przeszkadzać w niczym nie chce i według dekretu wyżej opisane[go], jeżelibym się pokazała nad zakazane miejsce, winną się daje wzięcia [...], Tak mi P[anie] Boże dopomóż, męka je[go] przenajświętsza i święci wszyscy" (APB, 196/74, s. 251-250 (odwrotna paginacja)). 
przysięgi"33. Podobne oświadczenie znajdujemy we wpisie nowskiej ławy z lipca 1728 r. Ławnik Krzysztof Trytt pozwał wtedy Michała Jungnikla do wysłuchania przysięgi swojej oraz małżonki (matki?). O ile Trytt świadectwo złożył, to Jungnikiel nie dopuścił jego żony „ponieważ już podeszła w leciach" ${ }^{34}$. Sąd zdecydował natomiast, że nie ma przeszkód do przeprowadzenia dowodu, przy czym nie znamy dokładnego wieku tej kobiety. Jeśli natomiast spojrzymy na wiek innych przysięgających - powodów czy oskarżonych, to zasada ta nie znajdowała potwierdzenia, a przynajmniej spotykamy cały szereg różnych wyjątków. Mianowicie w księgach miejskich pojawiają się zapisy o świadkach $70-{ }^{35}, 80-{ }^{36}, 90-{ }^{37}$ czy nawet 100-letnich ${ }^{38}$.

Osoba zobowiązana do przysięgi nie mogła odmówić, chyba że dysponowała mocniejszymi dowodami (np. dokumentami, wypisami z ksiąg urzędowych). Nawet powód, który „przez wzgląd na Boga lub prośbę bogobojnych ludzi", wnioskował o zwolnienie strony przeciwnej, musiał uzyskać zgodę sędziego ${ }^{39}$. Sprzeciw jakiegokolwiek innego uczestnika był równoznaczny z koniecznością przysięgania, tak jak $\mathrm{w}$ toczonym w 1749 r. przed kościerskim sądem postępowaniu spadkowym po Elżbiecie Mosińskiej. Kompletność inwentarza poprzysiągł mąż zmarłej, radny miasta Stanisław Mosiński. Nie uspokoiło to jednak innych spadkobierców, którzy zażądali, aby na krucyfiksie złożyła palce także podeszła wiekiem teściowa. Widząc jednak chęć kobiety do dokonania czynności, „podarowano sobie tego trudu”. Rota miała brzmieć: „Ja Marianna przysięgam Panu Bogu Wszechmogącemu w Trójcy Świętej Jedynemu, iż żadnej krzywdy dzieciom po córce mojej Elżbiecie pozostałym a wnukom moim nie uczyniłam ani pieniędzy, tudzież bielizny i szat nikomu ani z sprzętów ani z sprzętów domowych nie wydałam, ani przy sobie otrzymałam $[\ldots]^{\prime 40}$. Zaznaczono przy tym, że „Sąd niniejszy nakazuje

${ }^{33}$ APB, 196/23, s. 149.

${ }^{34}$ APB, 196/96, s. 285.

${ }^{35}$ Np. BZNiO, 4411/II, k. 1144v (Wegnat, 1607, Kościerzyna); APGd, 520/7, k. 73v-74 (Maciej Lipiński, Łukasz Lipiński, 1702, Skarszewy); APB, 196/106, s. 183 (1751, Nowe); APB, 196/101, s. 176 (1742, Nowe); APB, 196/103, s. 66 (1745, Nowe).

${ }^{36}$ Np. BZNiO, 4411/II, k. 71 (1599, Kościerzyna); tamże, k. 96v (1601, Kościerzyna); tamże, k. 127v (1605, Kościerzyna); APB, 1675/39, s. 304-305 (1694, Chojnice); APB, 196/97, s. 343 (1731, Nowe).

${ }^{37}$ Np. BZNiO, 4411/II, k. 122v (1605, Kościerzyna); tamże, k. 123 (1605, Kościerzyna); tamże, k. 128 (1605, Kościerzyna); APB, 196/99, s. 180 (1737, Nowe).

${ }^{38} \mathrm{~Np}$. BZNiO, 4411/II, k. 122v (1605, Kościerzyna).

${ }^{39}$ RL, s. 93, art. 29; por. M. Mikołajczyk, Proces kryminalny w miastach Małopolski..., s. 393.

${ }^{40}$ APGd, 506/4, k. 130. 
[przysięgę - P.K.], gdzie widząc chęć tejże Pani Kleszczyńskiej afektanta niegdy małżonki matki rodzonej do odłożenia przysięgi i klęknąwszy chciała w wyżej wyrażoną rotę poprzysiąc, więc afektant [Stanisław Mosiński - P.K.] teraźniejszy [z opiekunami dzieci spadkodawczyni - P.K.] przysięgi ustąpili". Z kolei jeśli pozwany chciał przysięgać to powód musiał dowód przyjąć bądź zapłacić - zgodnie z Rewizja Lidzbarska - cztery szelagi. Można było jednak postawić zarzut, w którym podważona była zdolność do jego odłożenia.

Złożenie fałszywej przysięgi, a więc potwierdzenie danego faktu niezgodnie z prawda, było równoznaczne z popełnieniem krzywoprzysięstwa. W pierwszej rewizji chełmińskiej, w art. 44 księgi III „O karze za krzywoprzysięstwo" ${ }^{41} \mathrm{i}$ art. 62 księgi IV zatytułowanym „O świadkach” nakazano, aby osobie, której udowodniono wiarołomstwo, obcięte zostały dwa palce, którymi składała przyrzeczenie oraz uznano ją za infami$\mathrm{sa}^{42}$. Było to odwołanie do regulacji prawa magdeburskiego, sankcję tę zaś powtarzały następnie Rewizja Nowomiejska i Toruńska ${ }^{43}$. XVI-wieczny prawoznawca Paweł Szczerbic wyjaśniał przy tym, czym było krzywoprzysięstwo $^{44}$. Lwowianin twierdził, że mogło być dokonane zarówno umyślnie, kiedy przysięgający świadomie potwierdzał nieprawdę, jak i nieumyślnie, gdy nie miał świadomości takiego działania. Karane miały być zatem również osoby, które przekonane o prawdziwości danych faktów poświadczały nieprawdę. Tej samej karze podlegali ci, którzy nie dotrzymywali danego w przysiędze słowa, np. w sprawie o zapłatę długu, rezygnacji z roszczeń czy wykupu nieruchomości. Nieważna była w tym miejscu kwestia poczytalności, a brak rozpoznania czynu mógł zostać uznany co najwyżej za okoliczność łagodzącą ${ }^{45}$.

$Z$ racji grożącej kary (doczesnej i wiecznej) przed złożeniem oświadczenia pouczano często o konsekwencjach prawnych wiarołomstwa. Wi-

\section{${ }^{41}$ RL, S. 132.}

${ }^{42}$ RL, s. 239. Odpowiednio w Prawie Starochetmińskim: „A w drugiej sprawie oskarżyli go o to, że świadomie dopuścił się krzywoprzysięstwa. Na to orzekamy jako prawo: Jeżeli zaprzeczy, to może się wedle prawa oczyścić przysięgą na Świętych zgodnie z prawem. Natomiast, jeżeli się przyzna, zostaje wyjęty spod prawa" (PS, s. 74, art. 48).

${ }^{43}$ RN, s. 70-71, art. 62.

${ }^{44}$ P. Szczerbic, Speculum Saxonum..., s. 192-193.

${ }^{45}$ Ciekawą definicję krzywoprzysięstwa przedstawił w swoim Chlebie duchownym ksiądz Jan Wuykowski. W tym, wielokrotnie wznawianym, przewodniku dobrego kapłana, zawierającym wiele przydatnych w codziennej posłudze wskazówek, pisał „Jest [to - P.K.] fałszywe świadectwo, utwierdzone przysięgą przed sędzią, co się dzieje, gdy kto porządnie seu juridice pytany, nie odpowiada według prawdy, albo intencji sędziego". Jan Stanisław Kostka Wuykowski, Chleb duchowny, wszystkim chrześcianom na posiłek w drodze, do Nieba idącym, wystawiony albo raczey katechizm, Kraków 1746, s. 218. 
dać to w treści niektórych rot. W $1728 \mathrm{r}$. nowski ławnik oświadczył: „Ja Stanisław Kuczora przysięgam Panu Bogu Wszechmogącemu w Trójcy Świętej Jedynemu, przez wszelkiej restrykcji szczerym sercem, iż jakom gospodarzem został, nigdym nie rozkazował parobkom moim jeździć do boru zamkowego drzewo na opał kraść i rąbać [...]. Tak mi Panie Boże dopomóż i męko niewinna albo mię Panie Jezu skarz za krzywoprzysięstwo"46. Cztery lata później kilkoro mieszczan przysięgało: „Ja Krystian Rabner, Ja Jadwiga Jungnikiel, Ja Konkordia Rabnerówna, przysięgam P[anu] Bogu Wszechmogącemu w Trójcy Świętej Jedynemu, który krzywoprzysiężce surowo karać będzie [...]"47, czy w 1742 r., kiedy to Katarzyna Bezler i jej kucharka oświadczyły: „Ja Katarzyna, Ja Ewa, przysięgam P[anu] Bogu Wszechmogącemu w Trójcy Świętej Jedynemu, iż to wszystko com widziała i słyszała, kiedy Berent żołnierz, męża mego bił i szkalował i córkę jego, a pasierbicę moją w domu moim, tego nie czynię z miłości męża mego i namowy dla utrzymania sprawy swojej, tylko z[e] szczególnej słuszności, obawiając się, żeby mię Bóg nie karał za krzywoprzysięstwo na strasznym sądzie bożym [...]"48. W 1670 r. w sprawie o zajazd i pobicie małżeństwa Bobrowskich, dzierżących dobra Polaszki, brali udział dwaj świadkowie. Mieli potwierdzić bieg wydarzeń i winę sprawców - braci Kalkszteinów. Jak zapisano, byli „zdrowi na ciele i na umyśle, będąc o fałszywym świadectwie [...] i krzywoprzysięstwo od urzędu napomnieni" ${ }^{49}$. Podobnych przykładów nie brakuje ${ }^{50}$.

Niekiedy dawano też czas na przygotowanie się do czynności (termin przysiężny ${ }^{51}$ ), zwykle nie przekraczający siedmiu dni (np. do następnej sesji sądu), choć nie było w tym przypadku reguły. W ten sposób wywierano nacisk na świadka, oskarżonego czy powoda, który mógł przemyśleć swoje stanowisko i, docelowo, miał powiedzieć prawdę. Z drugiej strony także zobowiązany miał prawo prosić o odroczenie terminu z powodu czynników obiektywnych (np. choroba, podróż, konieczność sprawowania funkcji publicznych) bądź osobistych (przygotowanie do jej złożenia), z tym że w tym drugim przypadku jego udzielenie zależało w dużej mierze od uznania sądu oraz strony przeciwnej.

${ }^{46}$ APB, 196/96, s. 247.

${ }^{47} \mathrm{APB}, 196 / 99$, s. 175.

${ }^{48}$ APB, 196/101, s. 156.

${ }^{49}$ APGd, 2/7, s. 93.

${ }^{50} \mathrm{BZNiO}, 4415 / \mathrm{II}, \mathrm{k}$. 22-22v (Christian Schmidt, 1669, Kościerzyna); APGd, 2/7, s. 618 (1672, Bartosz Hakowic, Kiszpork); APGd, 520/25, k. 21-22 (Otto Wilhelm Wedzek, Anna Maria Relowa, 1754, Skarszewy).

${ }^{51}$ S. Borowski, Przysięga dowodowa..., s. 47. 
Przestępstwo krzywoprzysięstwa wcale nie należało do rzadkich, choć $\mathrm{z}$ racji luk $\mathrm{w}$ materiale źródłowym (w szczególności brak ksiąg kryminalnych), trudno mówić o jego nadmiernej pospolitości ${ }^{52}$. Czy natomiast orzekano przewidzianą za nie karę? Liczne zapisy postępowań karnych świadcza, że nie, gdyż oskarżeni, których winę udowodniono lub było duże prawdopodobieństwo, że niebawem wyjdzie ona na jaw, odwoływali się zwykle do łaski rady. Takie prawo dawał np. art. 14, księgi I Rewizji Nowomiejskiej53: ,jeżeli ktoś wyzna dobrowolnie wobec rady, że popełnił przestępstwo, np. kradzież, krzywoprzysięstwo, prosząc o łaskę [...] rada może wobec przyznającego się i proszącego o łaskę orzec karę i prowadzić proces według [swego] uznania" ${ }^{24}$. I Ordynek mógł potraktować to jako okoliczność łagodzącą lub nawet odstąpić od wymierzenia kary. W tej sytuacji rajcy nie byli związani żadnymi przepisami prawa, a decyzja w tej sprawie była całkowicie autonomiczna, jako przejaw ich łaski. Dotyczyło to zarówno wymiaru kary, jak i rodzaju przestępstwa, do którego przyznał się podejrzany, gdyż katalog czynów wymienionych $\mathrm{w}$ artykule 14, jak zresztą większość $\mathrm{w}$ kodeksie, nie miał charakteru enumeratywnego. Już w Prawie Starochełmińskim podkreślono, że decyzja była niezależna od jakiejkolwiek władzy: "Jeżeli rada obwinia jednego z obywateli o przestępstwo dokonane przeciwko miastu, a ten zdaje się w związku z tym na ich łaskę i oni [rada] mu jej udzielają, a udzielić mogą i coś zostanie mu darowane, to ani książe, ani sędzia nadworny nie mają nic do tego i za to, że się zdał na łaskę rady i miasta, niczym wobec swych panów nie zawinił" 55. Przykładowo do krzywoprzysięstwa przyznała się w 1760 r. żona instygatora (sic!) Nowego, Gotarda Litkamera ${ }^{56}$. Pozostając na ten czas w separacji „od łoża i stołu”, poprzysięgła kompletność inwentarza wspólnych dóbr, pomimo że nie podała do niego kilku wartościowych składników. W momencie, gdy nie było innego wyjścia, otwarcie wyznała winę, odwołując się jednocześnie do sumienia rady. Ta postanowiła skazać ją na tydzień pobytu w wieży miejscowego ratusza, 10 florenów dla miejscowej fary, 12 grzywien dla sądu i tyleż dla powo-

${ }^{52}$ Np. APB, 1675/151, s. 70-71 (1767, Chojnice), APB, 1675/148, s. 46-47 (1767, Chojnice); APB, 196/98, s. 138-139 (1734, Nowe); APB, 196/109, s 140-141 (1755, Nowe); APB, 196/16, s. 150, 152; 161-162 (1690, Nowe); BG PAN, Acta Consularia, MS 1346, k. 63 (1661, Nowe).

${ }^{53} \mathrm{RN}$, s. $49-50$.

${ }^{54}$ Odpowiednio w Rewizji Lidzbarskiej „w tym przypadku [np. krzywoprzysięstwa - P.K.] rada jest władna osądzić przestępstwa jeśli ktoś zeznaje, że zdał się na łaskę rady i zależy też od rady jaką i w jakiej wysokości karę na niego nałożyć", RL, s. 133-134.

${ }_{55}^{5}$ PS, s. 76, art. 57.

${ }^{56}$ APB, 196/34, s. 176-177. 
da. Mężowi miała również zwrócić wszystkie koszty przeprowadzonego procesu $^{57}$.

Karane było również przekupywanie świadków w celu złożenia fałszywego oświadczenia. I tu jednak dość często sądy wykazywały zaskakujące zrozumienie, nakładając nie kary cielesne, a finansowe. W $1768 \mathrm{r}$. wpisano w księgi chojnickie sprawę toczoną między Michałem, Ertmanem i Krystianem Wernerami a młynarzem nazwiskiem Strelka o zadanie „niepodciwego urodzenia”, krzywoprzysięstwo oraz, dodatkowo, niewykonanie poprzednich dekretów. Mianowicie ten ostatni sprowadził osoby, „aby z naprowadzenia jego i perswazji bezbożnej według złośliwego jego umysłu świadczyli" 58 jak im polecił, co też ostatecznie wyszło na jaw. Za kalumnie krewki młynarz zapłacił 60 grzywien. Kwestię krzywoprzysięstwa rozpatrzono osobno. Udowodniono, że dał on świadkom po korcu grochu, za który to czyn „krwią [...] zmazany być powinien", lecz sędzia zdecydował, że skaże go na miesiąc wieży (,cztery niedziele”) oraz 200 grzywien - 100 dla sądu i 100 dla poszkodowanych ${ }^{59}$.

Podsumowując, przysięga miała istotne znaczenie jako dowód w pruskim postępowaniu sądowym. Nie znalazła jednak szerszego unormowania w stosowanych $\mathrm{w}$ prowincji zbiorach prawnych z XIV-XVI w. odnoszących się zarówno do szlachty, jak i mieszczaństwa. Dowód ten rozwijał się w sposób zwyczajowy pod wpływem prawa magdeburskiego, jego późniejszych komentarzy oraz praktyki lokalnej. Generalnie, w zakresie budowy przysięgi używanej w prawie Prus Królewskich nie widzimy zmian od średniowiecza, kiedy to utrwalił się jej schemat jako środka dowodowego. Był on tożsamy z tym znanym z Korony, czego przykładem mogą być nie tylko zapisy tamtejszego materiału sądowego ${ }^{60}$, ale również gotowe formularze, jak np. $\mathrm{z}$ dzieła XVIII-wiecznego prawoznawcy Teodora Ostrowskiego ${ }^{61}$ czy wspomnianego wcześniej Barłomieja Groickiego (XVI w.). Wydaje się natomiast, że wskazane przez tego ostatniego rozbu-

${ }^{57}$ Uznanie za krzywoprzysiężcę miało swoje skutki. Oprócz powyższych sankcji wynikających czy to z przepisu, czy z praktyki prawa, krzywoprzysiężca na równi z banita, heretykiem czy człowiekiem niepoczytalnym tracił zdolność procesowa, RL, s. 226-227, art. 46.

${ }^{58}$ APB, 1675/151, s. 240.

${ }^{59}$ Tamże, s. 241.

${ }^{60}$ S. Borowski, Przysięga dowodowa..., passim.

${ }^{61}$ T. Ostrowski, Prawo cywilne albo szczególne narodu polskiego z statutów i konstytucyi koronnych i litewskich zebrane rezolucyami Rady Nieustaiacej obiaśnione z dodatkami z praw kanonicznego, magdeburskiego, chełmińskiego pomnożone i porządkiem praw rzymskich, t. I, Warszawa 1784, s. 349-350. 
dowane wymogi formalne, podobnie jak w innych częściach Królestwa ${ }^{62}$, uległy w XVI-XVIII w. złagodzeniu, choć z racji rangi przysięgi dalej stosowano podniosły ceremoniał (klęczenie, kładzenie palców na krucyfiks, Biblię itd.), co miało unaoczniać wymiar religijny, ale również posiadało znaczenie praktyczne, wpływając na osobę ją składającą. Obok tego stopniowo odchodzono od stosowania sankcji za krzywoprzysięstwo przewidziane przez prawo pisane (obcięcie palców, infamia). Zastępowano je karami pieniężnymi i krótkoterminowym pozbawieniem wolności, szczególnie w przypadkach, gdy oskarżony zdał się na łaskę rady, a więc de facto przyznał się do winy.

\section{Bibliografia}

\section{Źródła rękopiśmienne}

Archiwum Państwowe w Bydgoszczy:

196/12, 196/16, 196/23, 196/34, 196/70, 196/74, 196/75a, 196/90, 196/92, 196/93, 196/96, 196/97, 196/98, 196/99, 196/101, 196/103, 196/106, 196/109, 1675/39, 1675/147, 1675/148, 1675/151.

Archiwum Państwowe w Gdańsku:

$2 / 7$,

$506 / 1,506 / 2,506 / 4$

$520 / 7,520 / 14,520 / 23,520 / 25$,

$524 / 10,524 / 13$.

Biblioteka Polskiej Akademii Nauk w Gdańsku:

MS 1346.

Biblioteka Zakładu Narodowego im. Ossolińskich we Wrocławiu:

3181/II, 3182/II, 4410/II, 4411/II, 4415/II.

\section{Źródła drukowane:}

Groicki B., Porzadek sądów i spraw miejskich prawa majdeburskiego w Koronie, wyd. K. Koranyi, Warszawa 1953.

Groicki B., Tytuły prawa maydeburskiego do porządku i do artykułów, pierwey po polsku wydanych. W sprawach tego czasu naywięcey ktopotnych $z$ tegoż prawa maydeburskiego przydatne, Kraków 1760.

Ius Culmense ex ultima revisione oder das vollständige Kulmische Recht, wyd. M. C. Hanow, Danzig 1745.

Ostrowski T., Prawo cywilne albo szczególne narodu polskiego z statutów $i$ konstytucyi koronnych i litewskich zebrane rezolucyami Rady Nieustaiacej obiaśnione z dodatkami z praw kanonicznego, magdeburskiego, chetmińskiego pomnożone i porzadkiem praw rzymskich, t. I, Warszawa 1784.

${ }^{62}$ S. Kutrzeba, Dawne polskie prawo sadowe w zarysie. (I. prawo karne, II. postępek sadowy), Lwów-Warszawa-Kraków 1927, s. 97-98. 
Patterson D., Ius terrestre nobilitatis prussiae correctum Anno Domini M. D. XCVIII, Gedani 1627.

Prawo starochetmińskie 1584 (1394), red. W. Maisel, Z. Zdrójkowski, przekł. A. Bzdęga, A. Gaca, Toruń 1985.

Rewizja lidzbarska prawa chetmińskiego 1566 [1711], przekł. A. Groth, Koszalin 1997.

Rewizja nowomiejska prawa chetmińskiego 1580 (1814) zwana także ius culmense emendatum lub ius culmense polonicum, red. Z. Zdrójkowski, przekł. I. Malinowska-Kwiatkowska, J. Sondel, Toruń 1993,

Szczerbic P., Speculum Saxonum albo prawo saskie y magdeburskie porzadkiem obiecadła, z laćinskich y niemieckich exemplarzow zebrane, Lwów 1581.

Volumina Legum, t. VI, wyd. J. Ohryzko, Petersburg 1860.

Wuykowski J. S., Chleb duchowny, wszystkim chrześcianom na positek w drodze, do Nieba idacym, wystawiony albo raczey katechizm, Kraków 1746.

\section{Opracowania}

Borowski S., Przysięga dowodowa w procesie polskim późnego średniowiecza, Warszawa 1926.

Dąbkowski P., Prawo prywatne polskie, t. I, Lwów 1910.

Duda M., Jóźwiak S., Sposoby składania przysięi w Państwie Zakonu Krzyżackiego w Prusach w późnym średniowieczu. Zarys problematyki, "Zapiski Historyczne” 2014, t. LXXIX, z. 1.

Duda M., Jóźwiak S., Ze świata średniowiecznej symboliki. Gest i forma przysięi w chrześcijańskiej Europie (X-XV w.), Kraków 2014.

Kitowski P., Radecka N., Normatywny model opieki nad sierotami w XVI-wiecznych rewizjach prawa chetminskiego. Zarys instytucji, CPH, 2012, t. LXIV, z. 1.

Kutrzeba S., Dawne polskie prawo sadowe w zarysie (I. prawo karne, II. postępek sadowy), Lwów-Warszawa-Kraków 1927.

Mikołajczyk M., Proces kryminalny w miastach Małopolski XVI-XVIII wieku, Katowice 2013.

Sedlar J. W., East Central Europe in Middle Ages, 1000-1500, Seattle 1994.

Wijaczka J., Polowanie na czarownice i czarowników w Nowem nad Wisła i najbliższej okolicy miasta w XVII i w pierwszej połowie XVIII wieku, "Czasy Nowożytne” 2009, t. XXII.

Wijaczka J., Procesy o czary przed sąami miejskimi i wojewodzińskimi w Skarszewach w końcu XVII i w pierwszej połowie XVIII wieku, [w:] Prusy i Inflanty między średniowieczem a nowożytnością. Państwo - społeczeństwo - kultura, red. B. Dybaś, D. Makiłła, Toruń 2003. 